\title{
Nutritional Interventions to Reduce Cardiovascular Risk Factors: An Iranian Perspective
}

\author{
Parvin Mirmiran ${ }^{1,2}$, Zeynab Amirhamidi ${ }^{1}$, Zahra Bahadoran', Sahar Mirzaiee', Fereidoun Azizi ${ }^{3}$, \\ ${ }^{1}$ Nutrition and Endocrine Research Center, Research Institute for Endocrine Sciences, Shahid Beheshti University of Medical Sciences, \\ Tehran, Iran \\ ${ }^{2}$ Department of Nutrition and Diet Therapy, Faculty of Nutrition Sciences and Food Technology, National Nutrition and Food Technology \\ Research Institute, Shahid Beheshti University of Medical Sciences, Tehran, Iran \\ ${ }^{3}$ Endocrine Research Center Research Institute for Endocrine Sciences, Shahid Beheshti University of Medical Sciences, Tehran, Iran
}

\section{Email address:}

Azizi@endocrine.ac.ir (F. Azizi)

\section{To cite this article:}

Parvin Mirmiran, Zeynab Amirhamidi, Zahra Bahadoran, Sahar Mirzaiee, Fereidoun Azizi. Nutritional Interventions to Reduce Cardiovascular Risk Factors: An Iranian Perspective. International Journal of Nutrition and Food Sciences. Special Issue: Nutrition and Cardiometabolic Risk Factors. Vol. 5, No. 1-2, 2016, pp. 1-7. doi: 10.11648/j.ijnfs.s.2016050102.11

\begin{abstract}
Cardiovascular disease (CVD) is the most leading cause of morbidity and mortality worldwide. Despite efficacies of currently available clinical and pharmaceutical approaches for the control of CVD risk factors, it seems that designing and developing of population-based interventions reducing tobacco use, advocating of physical activity, reducing harmful alcohol use, and promoting healthy diet is a cost-effective, permanent way and could play a major role in reduction of the burden of CVD. In this study, we reviewed some population-wide interventional programs and some nutritional intervention studies designed to prevent cardiovascular disease among Iranian populations.
\end{abstract}

Keywords: Cardiovascular Disease, Dietary Intervention, Population-Based Study, Lifestyle Changes

\section{Background}

Cardiovascular disease (CVD) is the leading cause of morbidity and mortality worldwide and there is global concern regarding the alarming increasing trend of cardiovascular risk factors especially among developing countries [1]. More than 7.3 million deaths and 58 million disability adjusted life years lost worldwide due to CVD were reported in 2001 [2]. Among Middle East countries, Iran probably has highest burden of heart disease [3]. In a population-based study, age-adjusted prevalence of coronary heart disease was $21.8 \%$ (22.3 and $18.8 \%$ in men and women, respectively) [4]. Despite the lack of accurate data, evidence shows that coronary artery disease (CAD) has an increasing trend in recent years with studies showing that age-adjusted mortality from CAD increased by $20-45 \%$ in an Iranian population [5].

Some important metabolic/physiological risk factors which contribute to the development of CVD, include overweight and obesity, hypertension, diabetes and dyslipidemia [6]. The age-adjusted prevalence of metabolic syndrome, a main risk factor for development of cardiovascular disease, among Iranian urban adults was $33.7 \%$ (95\% CI: 32.8-34.6) and low-HDL-C was the most common metabolic abnormality in the population [5].

Low physical activity, use of tobacco and alcohol are also modifiable behavioral risk factors of cardiovascular disease; among these lifestyle factors, unhealthy diet, including low fruit and vegetable consumption, regular consumption of high-energy foods, processed foods, higher intake of salt, fats, saturated and trans fats, as well as dietary cholesterol play critical roles [6]. Consumption of imbalance diets with high energy and low nutrient density has been indicated as a main factor for developing of non-communicable diseases especially cardiovascular disease among Iranian populations [7]. Several studies report rapid ongoing nutrition transition in Iran, with a progressive shift to a westernized dietary pattern, in particular higher consumption of processed foods, sweetened beverages, outof-home meals and fast foods, and energy-dense unhealthy snacks; this transition plays a critical role in the development of cardiometabolic risk factors among Iranian population [8-10].

Despite efficacies of clinical and pharmaceutical approaches available in the control of CVD risk factors, it 
seems that designing and developing population-wide interventions through reducing tobacco use, promotion of physical activity, reducing harmful alcohol use, and promoting healthy diet is a cost-effective, permanent measure and may play a major role in reduction of the burden of CVD[6]. In fact, the ideal approach to promote cardiovascular health is prevention of cardiovascular risk factors via interventions within health systems, and community-based programs conducted in schools, worksites, and other community settings [11]. Several national and cost-effective nutritional interventions for cardiovascular health have been conducted worldwide; of which the main ones include population-wide sodium reduction, replacement of polyunsaturated margarines with butter, population-wide policies to promote healthy eating and adoption of the Dietary Approaches to Stop Hypertension (DASH) diet, population-wide policies to reduce dietary fat intake and increase fresh fruits and vegetables, reformulation and development of healthier food products to promote a healthy diet, and priceintervention policies including taxes, subsidies, price promotions and other economic incentives [12-14].

In this study, we reviewed main population-wide interventional programs and some nutritional intervention studies designed to prevent cardiovascular disease among Iranian populations. To identify relevant studies, we performed literature searches in Scopus, PubMed, Science Direct, Google Scholar and SID databases for articles published up to July 2014. Search terms included "cardiovascular disease", "risk factor", "Iran", "populationbased intervention", "lifestyle" and "nutrition".

\section{Large Scale Community-Based Interventional Projects}

\author{
Isfahan Healthy Heart Program
}

Table 1. Brief description of the main intervention projects of the Isfahan Healthy Heart Program [15].

\begin{tabular}{|c|c|}
\hline Project name & Main intervention \\
\hline Healthy Food for Healthy Community & $\begin{array}{l}\text { Educating about healthy cooking methods and making high-fibre, low-salt bread; promoting the production of } \\
\text { healthy food products by food industries; modifying food labels; educating the public on the concept of healthy } \\
\text { nutrition; improving the formulations in confectioneries; introducing healthy brands and half-portions in } \\
\text { restaurants and fast food eateries }\end{array}$ \\
\hline $\begin{array}{l}\text { Isfahan Exercise and Air Pollution } \\
\text { Control Project }\end{array}$ & $\begin{array}{l}\text { Providing training on exercise and physical activity through local television; distributing educational CDs } \\
\text { about exercise at home and at the worksite; organizing public exercise rallies, automobile-free days and healthy } \\
\text { heart exhibitions; educating about air pollution control methods through local television; advocating the } \\
\text { development of bicycle lanes in the city }\end{array}$ \\
\hline Women Healthy Heart Project & $\begin{array}{l}\text { Providing healthy lifestyle training to young women attending pre-marriage classes and their family members, } \\
\text { as well as instructors of the literacy campaign movement and their students, instructors of charities, women in } \\
\text { the Basij Movement (coalitions within mosques), women in different organizations, women attending health } \\
\text { centers and health houses, and female volunteer instructors of the Red Crescent Society; educating the public } \\
\text { through television and cook books; distributing a CD about methods of physical activity requiring no special } \\
\text { facilities }\end{array}$ \\
\hline Heart Health Promotion from Childhood & $\begin{array}{l}\text { Providing healthy lifestyle training to children, parents, health professionals and school and kindergarten staff } \\
\text { about healthy lifestyles; promoting physical activity in schools and kindergartens; introducing healthy snacks in } \\
\text { schools and kindergartens; establishing healthy buffets in schools; forming role model groups from volunteer } \\
\text { students; providing practical training through television about healthy lifestyles; screening for cardiovascular } \\
\text { disease risk factors in children of patients with premature cardiovascular disease and in children with at least } \\
\text { one risk factor, such as obesity }\end{array}$ \\
\hline Youth Intervention Project & $\begin{array}{l}\text { Providing healthy lifestyle training to volunteers from the Red Crescent Society, garrison instructors, soldiers } \\
\text { in their mandatory military service and university students, as well as kitchen staff of universities and } \\
\text { garrisons; conducting an international anti-smoking Quit \& Win campaign }\end{array}$ \\
\hline Worksite Intervention Project & $\begin{array}{l}\text { Providing healthy lifestyle training to occupational medicine physicians or health assistants; introducing dietary } \\
\text { modifications into factory restaurants; enforcing no-smoking regulations at worksites; using the existing } \\
\text { screening system to detect high-risk groups; promoting physical activity at worksites; providing health } \\
\text { messages about cardiovascular disease prevention in official newsletters of different organizations }\end{array}$ \\
\hline $\begin{array}{l}\text { Non-Governmental Organizations and } \\
\text { Volunteers Project }\end{array}$ & $\begin{array}{l}\text { Training health workers in cities and villages; forming, training and empowering an assembly of health } \\
\text { volunteers; training community members in performing physical activity in the absence of facilities, healthy } \\
\text { nutrition and coping with stress via trained volunteers and health-related nongovernmental organizations }\end{array}$ \\
\hline Health Professionals Education Project & $\begin{array}{l}\text { Establishment of educational assemblies; training general practitioners by continual medical education courses; } \\
\text { training physicians through periodical seminars; training nurses by forming educational assemblies; publishing } \\
\text { and distributing books and newsletters among nurses and other health professionals in urban and rural areas; } \\
\text { running information campaigns on various occasions }\end{array}$ \\
\hline Healthy Lifestyle for High-Risk Groups & $\begin{array}{l}\text { Providing healthy lifestyle training to health-system personnel, high-risk individuals and retired employees; } \\
\text { activating clinics at hospitals; training the public; distributing educational brochures to people attending } \\
\text { pharmacies; printing health messages on laboratory report sheets }\end{array}$ \\
\hline $\begin{array}{l}\text { Healthy Lifestyle for Cardiovascular } \\
\text { Patients Project }\end{array}$ & $\begin{array}{l}\text { Providing healthy lifestyle training to patients and their families at the time of hospital discharge; printing cards } \\
\text { for patients to record all necessary information related to their disease; establishing rehabilitation units at all } \\
\text { heart } \\
\text { hospitals; improving nutritional and cooking procedures at hospital restaurants; distributing educational folders } \\
\text { containing educational materials on cardiovascular-disease secondary prevention and rehabilitation }\end{array}$ \\
\hline
\end{tabular}


The Isfahan Healthy Heart Program is one of the comprehensive integrated community-based interventional programs aimed at modifying coronary heart disease and stroke risk factors and improving the Knowledge, Attitude and Practice (KAP) of both the general community and health professionals regarding these factors and their prevention. This study was an intervention consisting of three stages performed by Kelishadi et al. over a period of 6 years. In the first stage in 1379several cross-sectional studies were conducted on adults, children, health workers and patients with heart disease and stroke to determine existing level of KAP among people (adults and children), health workers and patients, the prevalence of risk factors, coronary artery disease and stroke and mortality and morbidity resulting from these diseases in Esfahan and Najafabad (intervention counties) and Arak (control area). The20800 subjects included 12600 healthy subjects aged over 19 years, 2000 children aged 6-18 years and their parents, 500 school teachers and principals, 1700 health workers and 2000 cardiovascular patients. In the second stage, based on the results of surveys conducted in the first phase, the interventions including 10 projects (women, children, youth, individuals in worksite, health workers, non-governmental organizations and volunteers, high risk individuals, cardiovascular patients and nutrition and exercise project)was begun in 1380 in the total population. These intervention projects are described in table1 [15]. Interventions were performed in three groups including health workers, the general public (children and adults) and high risk individuals. Among health professionals, the purpose was teaching algorithms to control risk factors, simple methods for rehabilitation and secondary prevention of heart disease and cardiopulmonary resuscitation via seminars, workshops, lectures, distribution of pamphlets and posters and preparation of algorithms for control of cardiovascular and stroke risk factors. In the general public, the target was lifestyle modification in the field of cardiovascular disease and stroke and their risk factors as well as their prevention and control. This training was done through face to face education, holding competitions and lectures in different communities, workplaces, the usage of mass media such as radio, television, magazines and newspapers, allocation of exercise hours in worksites and collaboration with non-governmental organizations. Among individuals of the high risk group, interventions were carried out in patients with heart disease and stroke, their children, and families and for people having at least one cardiovascular risk factor. The goal was to teach subjects how to control risk factors, and to introduce them to the symptoms of these diseases, medications and their side effects, highlighting the importance of prevention since childhood and increasing awareness of the importance of rehabilitation and secondary prevention. This training took place by educating individuals regarding appropriate dietary pattern, not smoking and doing regular exercise, using simple pamphlets about the disease, its symptoms, medications and treatment and a prevention guide in the intensive care sections of the hospitals and holding training courses in cooperation with various organizations. After 3-4 years, in third stage, in the last year of the program in 1384, all surveys that were performed in the first stage were repeated in a random population of the intervention and control areas. The interventional program were assessed by determination of the changes in the prevalence of risk factors, mortality and morbidity of heart and stroke patients, KAP changes and related costs in intervention areas compared with the control area [16].

Several studies were conducted during this program; in one, a semi-experimental study, 12345 residents from a central area of Iran who had participated in the Isfahan Healthy Heart Project, were divided in two groups (an intervention group from Isfahan province and a control group from Arak) and were investigated and intervened in three stages. The first step included surveys before interventions, the second stage consisted of executive and educational interventions and provision of healthy nutrition programs in food catering in specifically for the intervention group andthe third phase included surveys after interventions. The results showed that after one year following initiation of the study, the average score of knowledge and performance related to proper nutrition increased in all age groups and both sexes, the rate of increase being higher in the intervention group in comparison to controls [17].

Another study, in order to design community-based interventions for prevention and control of cardiovascular risk factors, was conducted on 2000, 11-18 year old students selected by multi-stage simple random sampling, their parents and 500 school officials in Isfahan province as the intervention area and Arak as the control region. In this study the status of serum lipids in adolescents and its association with diet and Behavior, Attitudes, Skills and Knowledge (BASK) of students, parents and school officials were evaluated. The results showed that most of the students, parents and school officials had sufficient knowledge of healthy nutrition, but they lacked compliance. More families despite being aware of the fact that liquid oil is healthier than solid oil, used more solid oil, which could have been due to the lower price and easier access to solid oil. Although the average fat intake in adolescents $(21.2 \pm 0.4 \%)$ was in the recommended range $(\leq 30 \%)$, in many cases there were blood lipid disorders. This study showed a significant direct correlation between total cholesterol and consumption frequency of red meat, fatty snacks, fried foods and fast foods (sandwiches and pizza) and also a significant relationship between $\mathrm{TG}$ and intake frequencies of red meat, fatty snacks, fried foods, fast foods and rice intake. Findings demonstrating a significant association between serum LDL$\mathrm{C}$ level and the intake frequency of fried foods as well as an inverse relationship between serum HDL-C level and frequency of red meat, fatty snacks and fast foods (sandwiches and pizza) consumption [18].

Another community-based trial was conducted within the 
framework of the Isfahan healthy heart program to evaluate the effects of the Isfahan healthy heart project on diet, physical activity and smoking in two intervention areas compared to the control area; results indicated that after 4 years, a significant increase occurred in percentage of subjects who consumed healthy diets among the intervention group; leisure time physical activities increased in all areas and daily smoking decreased by $0.9 \%$ in the intervention areas and by $2.6 \%$ in the control area [15].

Results of 5-year interventions of the Worksite Intervention Project of the Isfahan healthy Heart Program on cardiovascular risk factors, showed that the prevalence of hypertriglyceridemia and central obesity decreased in both office staff and factory workers, but that of low HDL increased. Moreover a decline in the mean values of waist circumference, HDL and total cholesterol and an increase in diastolic BP and fasting BS were reported in both worksites of the intervention group [19].

Finally, another study conducted for evaluation of Healthy Lifestyle for Cardiovascular Patients Project implementation (HLCP). In HLCP, developed five main strategies to achieve goals such as a reduction in cardiovascular events, its risk factors and morbidity and mortality in heart patients. Interventions were designed on the basis of education, legislation and facilitating cooperation between different sectors and individuals. The contents of training programs in all interventions included the introduction of CVD, causes of its development or reversal, its risk factors, and control and prevention methods, appropriate pharmacological treatments, medications related to secondary prevention in particular, and non pharmacological treatments such as lifestyle modification including proper nutrition, quitting smoking, increasing physical activity and dealing with stress; this study also reviewed the effects of the project on taking medications for secondary prevention in patients with cardiovascular disease and the findings specified that among implemented interventions, training patients at the time of hospitalized, hospital discharge and after that, were successful interventions. In addition, motivating and mobilizing people for collaboration with a non-governmental organization, in the field of integration of secondary prevention programs in the community, was one of the successes of this project. Besides taking aspirin, beta blockers, angiotensin converting enzyme inhibitor (ACE-1) and statins significantly increased during the study in patients with CVD [20].

\section{Tehran Lipid and Glucose Study}

The Tehran Lipid and Glucose Study (TLGS) is the other integrated community-based program conducted by Azizi et al. in Iran to determine the risk factors for noncommunicable disorders (NCD) among Tehran's urban population and perform population-based measures to modify the lifestyle and prevent incidence of diabetes mellitus and dyslipidemia, cardiovascular risk factors; 17000 men and women 3-69 years old were randomly selected to assess conventional and emerging cardiovascular risk factors [21].This ongoing study began in 1999 and it will continue for at least 20 years. It has several phases, of which phase II, lifestyle interventions were implemented in 5630 people as the intervention group and 9375 individuals as the controls. The aim of the interventions were lifestyle modification by improving dietary pattern, increasing physical activity levels, and smoking cessation and as a result, primary, secondary and tertiary preventions for NCD. Dietary interventions were designed according to the KAP study, implemented earlier. The KAP study included several questions related to factors of weight change, fat sources, fibers, snacks and food groups. Interventional strategies were based on changes in school programs, educating health care volunteers and treating patients with NCD risk factors. The specific target groups were schoolchildren, housewives and high-risk people and the intervention group received the interventions through face to face education, leaflets and brochures [22].

In one study done on a sub-sample of participants in TLGS to assess the diet and conduct some nutritional interventions.316 subjects aged $\geq 20$ were selected and divided into 2 groups, case group (133 subjects) and control group (183 subjects). Mean energy and macronutrients intakes were measured and compared within the two groups, and results indicated a significant decline in mean energy, carbohydrate and fat intake and a significant increase in cholesterol intake in both groups. Moreover the prevalence of low HDL and central obesity increased in the controls, while hypercholesterolemia and high LDL cholesterol decreased in cases [23].

\section{Other Studies}

Other studies have also been conducted among Iranian populations regarding nutritional and lifestyle interventions; one of these is a semi-experimental study performed on 118 married women, to design and evaluate the precede planning model for improving nutritional behavior in a rural community. The precede method, a successful model, which is widely used for planning health promotion interventions, is based on this fact that a proper educational diagnosis can help design appropriate interventional programs. The 7 steps of this model include social, epidemiological, behavioral, educational (predisposing, enabling and reinforcing factors) and managerial diagnosis and evaluation. The aim is to enable health training professionals in the systematic planning, implementation and evaluation of educational programs. In this survey, based on the steps of the precede model, the mortality of CVD as the most important social problem, improper food habits as the most important health problem, and nutritional behaviors as the most important behavioral problem were selected. The educational programs included training sessions, providing posters, booklets and pamphlets in order to introduce people to cardiovascular disease, its complications and symptoms, the types of food groups and nutrients and dietary habits contributing to the development or reduction of the disease. In the evaluation step, the effects of the program on the predisposing, enabling and 
reinforcing factors were measured at immediately and 3 months after intervention. The findings indicated a significant increase in the structures of the precede model and an improvement in the predisposing, enabling and reinforcing factors. Moreover the relationship between knowledge and favorable behavior was significant [24].

The other study of this category is a randomized controlled trial implemented in postmenopausal Iranian women to discover the effect of a 6-month diet intervention on reducing cardiovascular risk factors. As documented, menopause is one of the CVD risk factors because estrogen withdrawal can be harmful for cardiovascular system. In this study 64 healthy postmenopausal women were chosen and were divided in to the intervention group $(n=35)$ and controls $(n=29)$. Intervention strategies included two face to face education sessions, three lecture discussion sessions about menopause, CVD and healthy diet. Subjects were educated on adequate consumption fruits and vegetables, whole grain, fibers and fish and also limited intakes of fat and salt. Results after 6 months indicated that weight, body mass index and fasting blood sugar were significantly lower whereas there were a significant increase in intakes of fiber, a significant decline in consumption of sodium in the intervention group, in comparison with the control group. Besides participants in the diet group consumed fruits and vegetables more than 5 servings a day [25]. Some other nutritional clinical trials conducted in small population are shown in table 2.

Table 2. Characteristics of some interventional studies focusing cardiovascular disease in Iran.

\begin{tabular}{|c|c|c|c|c|}
\hline Reference & Author & Population & Intervention & Results \\
\hline [27] & $\begin{array}{l}\text { Mahmoodi } \\
\text { M, et al }\end{array}$ & $\begin{array}{l}75 \text { postmenopausal } \\
\text { women with type } 2 \\
\text { diabetes }\end{array}$ & $\begin{array}{l}\text {-Three groups: } \\
\text { group 1: } 1.8 \mathrm{~g} \text { omega-3 fatty acids plus } 400 \mathrm{mg} \\
\text { vitamin } \mathrm{E} \text {, } \\
\text { group 2: } 5 \mathrm{mg} \text { zinc plus } 300 \mathrm{mg} \text { vitamin } \mathrm{C} \text {, group } \\
\text { 3: placebo } \\
\text {-For } 12 \text { weeks }\end{array}$ & $\begin{array}{l}\text { At baseline, there were no significant differences in } \\
\text { glycemic parameters among the three groups. Changes } \\
\text { in HOMA-IR in group } 1 \text { were significantly higher than } \\
\text { those in group } 2 \text { and the placebo group After } \\
\text { intervention, the change in fasting plasma insulin was } \\
\text { higher in group } 1 \text {, while it was lower in the other } 2 \\
\text { groups. The supplementation caused a significant } \\
\text { decrease in the mean changes in fasting plasma } \\
\text { glucose in group } 1 \text { and a significant increase in group } 2 \\
(-11.1 \pm 14.1 \text { vs. } 27.9 \pm 10.9 \mathrm{mg} / \mathrm{dl} \text {, respectively), }(\mathrm{p}= \\
0.039)\end{array}$ \\
\hline [28] & $\begin{array}{l}\text { Haghighat } \\
\mathrm{N} \text {, et al }\end{array}$ & 69 diabetic patients & $\begin{array}{l}\text {-Two groups: } \\
\text { the intervention group }(\mathrm{n}=32): 25 \text { gr dark } \\
\text { chocolate (containing } 450 \mathrm{mg} \text { polyphenols) } \\
\text { the control }(\mathrm{n}=28) \text { group: similar amount of white } \\
\text { chocolate } \\
\text {-For } 8 \text { weeks }\end{array}$ & $\begin{array}{l}\text { The intervention brought about statistically significant } \\
\text { reductions in the blood levels of TG, apo-lipoprotein } \\
\text { A-1, apo-lipoprotein B and hs-CRP. There were no } \\
\text { significant differences in either group with regard to } \\
\text { serum total cholesterol, LDL-c or HDL-c levels at the } \\
\text { end of the period; neither were observed any } \\
\text { intergroup differences }\end{array}$ \\
\hline [29] & $\begin{array}{l}\text { Yavari P, et } \\
\text { al }\end{array}$ & $\begin{array}{l}\text { A randomized, } \\
\text { controlled, double- } \\
\text { blind clinical trial on } \\
125 \text { patients with type } \\
2 \text { diabetes }\end{array}$ & $\begin{array}{l}\text {-Five groups: } \\
\text { 1) } 10 \mathrm{mg} \text { of B12, } \\
10 \mathrm{mg} \text { of B6, } \\
200 \text { micrograms of B12 And } 1,000 \text { micrograms } \\
\text { of folate } \\
\text { 2)Vitamin B complex, and } 100 \text { milligrams of } \\
\text { vitamin E } \\
\text { 3)Vitamin B complex, } 200 \mathrm{mg} \text { of vitamin C } \\
\text { 4) Vitamin B complex, } 100 \text { milligrams of vitamin } \\
\text { E, } 200 \text { mg of vitamin C } \\
\text { 5)Placebo } \\
\text {-For } 2 \text { months }\end{array}$ & $\begin{array}{l}\text { After } 2 \text { months, no significant changes in mean serum } \\
\text { apolipoproteins were seen But Significant positive } \\
\text { correlation between the changes vitamin E and apo A1 } \\
\text { and apo B changes were reported }\end{array}$ \\
\hline$[30]$ & $\begin{array}{l}\text { Sadeghifa } \\
\mathrm{J} \text {, et al }\end{array}$ & $\begin{array}{l}\text { A descriptive and } \\
\text { interventional study on } \\
96 \text { patients of } \\
\text { CCU and Post CCU of } \\
\text { Mustafa Khomeini } \\
\text { hospital of Ilam }\end{array}$ & $\begin{array}{l}\text { After educational intervention on knowledge and } \\
\text { attitude of patients in field of cardiovascular risk } \\
\text { factors }\end{array}$ & $\begin{array}{l}\text { Knowledge of patients in field of cardiovascular } \\
\text { disease before ( } 25.93) \text { and after ( } 36.19) \text { education, had } \\
\text { a significant difference. Moreover there was a } \\
\text { significant difference between before (23.5) and after } \\
\text { (35.7) education in attitude mean score }\end{array}$ \\
\hline [31] & $\begin{array}{l}\text { Paziraei } \\
\text { M.et al }\end{array}$ & $\begin{array}{l}36 \text { men non-athletes } \\
\text { aged } 57 \text { years }\end{array}$ & $\begin{array}{l}\text {-4 groups: } \\
\text { 1: exercise with } 2000 \mathrm{mg} \text { omega-3 supplement, } \\
\text { 2: exercise with placebo, } \\
\text { 3: } 2000 \mathrm{mg} \text { omega-3 supplement } \\
\text { 4: placebo } \\
\text {-For } 8 \text { weeks }\end{array}$ & $\begin{array}{l}\text { A decline by } 3.6 \% \text { inthe exercise }+ \text { supplement group, } \\
\text { by } 12.4 \% \text { in the exercise + placebogroup andby } 2.8 \% \\
\text { in the omega- } 3 \text { supplement group were reported }\end{array}$ \\
\hline [32] & $\begin{array}{l}\text { ArablouT, } \\
\text { et al }\end{array}$ & $\begin{array}{l}\text { A randomized } \\
\text { controlled double- } \\
\text { blind clinical trial on } \\
63 \text { type } 2 \text { diabetic } \\
\text { Patients }\end{array}$ & $\begin{array}{l}-2 \text { groups: } \\
\text { 1: the intervention group }(n=33): 1600 \mathrm{mg} \text { ginger } \\
\text { powder } \\
\text { 2: the control group }(n=30): 1600 \mathrm{mg} \text { placebo } \\
\text { containing wheat flour } \\
\text {-For } 12 \text { weeks }\end{array}$ & $\begin{array}{l}\text { Ginger could reduce fasting plasma glucose, } \\
\text { triglyceride, total cholesterol and C-reactive protein, } \\
\text { significantly in intervention group compared to } \\
\text { placebo group }\end{array}$ \\
\hline
\end{tabular}




\begin{tabular}{|c|c|c|c|c|}
\hline Reference & Author & Population & Intervention & Results \\
\hline [33] & $\begin{array}{l}\text { Raufi A, et } \\
\text { al }\end{array}$ & $\begin{array}{l}58 \text { patients with } \\
\text { elevated LDL } \\
\text { cholesterol } \\
\text { levels }\end{array}$ & $\begin{array}{l}\text {-Two groups: } \\
\text { 1) controlgroup: lovastatin, } \\
\text { 2) case group:lovastatin + Rhuscoriria } \\
\text {-For } 3 \text { months }\end{array}$ & $\begin{array}{l}\text { After intervention, the mean level of LDLdecreased in } \\
\text { both groups. The decline of LDL level was } 17 \% \text { in the } \\
\text { casegroup while was } 18 \% \text { in thecontrols }\end{array}$ \\
\hline [34] & $\begin{array}{l}\text { BagheriN, } \\
\text { et al }\end{array}$ & $\begin{array}{l}\text { A randomized clinical } \\
\text { trial on } 60 \\
\text { hypertensive patients }\end{array}$ & $\begin{array}{l}\text {-Two groups: } \\
\text { 1: placebo group } \\
\text { 2: experimental group: a capsule containing } 100 \\
\text { mg coenzyme Q10 } \\
\text {-For } 3 \text { months }\end{array}$ & $\begin{array}{l}\text { In experimental group, the median Systolic Blood } \\
\text { Pressure (SBP) before and after the intervention were } \\
150 \text { and } 130 \mathrm{mmHgrespectively.In} \mathrm{addition,} \mathrm{there} \mathrm{was} \\
\text { no significant difference in the median SBP between } \\
\text { two groups before the intervention, but it was } \\
\text { significant atthe end of the intervention }\end{array}$ \\
\hline [35] & $\begin{array}{l}\text { JavadiSh,e } \\
\mathrm{t} \text { al }\end{array}$ & 6 normal adult dogs & $\begin{array}{l}\text { Each of the dogs were administered normal saline } \\
\text { (control) and hydro-alcoholic extract of walnut } \\
\text { (intervention) }\end{array}$ & $\begin{array}{l}\text { Normal Saline had no effect on blood pressure and } \\
\text { serum aldosterone and renin, whereas blood pressure } \\
\text { reduced } 15 \text { minutes after the last administration of the } \\
\text { extract and renin increased } 15 \text { minutes after } \\
\text { administration of the extract so, the ratio of aldosterone } \\
\text { to renin significantly reduced }\end{array}$ \\
\hline [36] & $\begin{array}{l}\text { Baljany A, } \\
\text { et al }\end{array}$ & $\begin{array}{l}\text { A semi-experimental } \\
\text { study on } 86 \text { patients } \\
\text { with cardiovascular } \\
\text { disease }\end{array}$ & $\begin{array}{l}\text {-Two Groups: } \\
\text { 1) intervention group: self-management } \\
\text { interventions related to healthy lifestyle and long- } \\
\text { term adherence to medication treatment } \\
\text { 2) control group: routine interventions } \\
\text {-For } 6 \text { months }\end{array}$ & $\begin{array}{l}\text { Self-management interventions could help patients } \\
\text { with cardiovascular disease control themselves }\end{array}$ \\
\hline
\end{tabular}

\section{Conclusion}

Community-based intervention programs are considered as the best and most cost-effective strategies in the management of cardiovascular disease risk factors to decrease CVD mortality and morbidity [16]. In Iran, currently two ongoing large scale community-based intervention programs including the Isfahan Healthy Heart Program (IHHP) and the Tehran Lipid and Glucose Study (TLGS) being conducted. Both studies emphasize the effectiveness of such programs on cardiovascular disease prevention and control. Due to the high prevalence of CVD and its risk factors in Iran, more large community-based educational interventional studies are necessary in order to find proper solutions for the control of the disease and its risk factors. Moreover it must be emphasized that at the time of the implementation of such programs, the ways of encouraging public involvement should be carefully reviewed, implementer must use the advantages of effective interventions like improving the attitude and motivation of individuals and finally the implementation of these programs ought to be supported by the necessary legislation and accurate monitoring [26].

\section{References}

[1] Brown JR, O'Connor GT. Coronary heart disease and prevention in the United States. The New England journal of medicine. 2010 ; 362(23): 2150-3.

[2] Guilbert J. The world health report 2002-reducing risks, promoting healthy life. EDUCATION FOR HEALTHABINGDON-CARFAX PUBLISHING LIMITED-. 2003; 16(2): 230 .

[3] Gaziano TA, Bitton A, Anand S, Abrahams-Gessel S, Murphy A. Growing epidemic of coronary heart disease in low-and middleincome countries. Current problems in cardiology. 2010; 35(2): $72-115$.
[4] Hadaegh F, Harati H, Ghanbarian A, Azizi F. Prevalence of coronary heart disease among Tehran adults: Tehran Lipid and Glucose Study. East Mediterr Health J. 2009; 15(1): 157-66.

[5] Azizi F, Salehi P, Etemadi A, Zahedi-Asl S. Prevalence of metabolic syndrome in an urban population: Tehran Lipid and Glucose Study. Diabetes research and clinical practice. 2003; 61(1): 29-37.

[6] WHO. Global status on noncommunicable diseases. 2010; Available from: www.who.int $/ \mathrm{nmh} /$ publications/ncd_report_full_en.pdf.

[7] Ghassemi H, Harrison G, Mohammad K. An accelerated nutrition transition in Iran. Public health nutrition. 2002; 5(1a): 149-55.

[8] Djazayery A, Pajooyan J. Food consumption patterns and nutritional problems in the Islamic Republic of Iran. Nutrition and Health. 2000; 14(1): 53-61.

[9] Bahadoran Z, Mirmiran P, Hosseini-Esfahani F, Azizi F. Fast food consumption and the risk of metabolic syndrome after 3years of follow-up: Tehran Lipid and Glucose Study. European journal of clinical nutrition. 2013.

[10] Mirmiran P, Bahadoran Z, Delshad H, Azizi F. Effects of energy-dense nutrient-poor snacks on the incidence of metabolic syndrome: A prospective approach in Tehran Lipid and Glucose Study. Nutrition. 2014; 30(5): 538-43.

[11] Kelly BB, Fuster V. Promoting Cardiovascular Health in the Developing World:: A Critical Challenge to Achieve Global Health: National Academies Press; 2010.

[12] Appel LJ, Frohlich ED, Hall JE, Pearson TA, Sacco RL, Seals $\mathrm{DR}$, et al. The importance of population-wide sodium reduction as a means to prevent cardiovascular disease and stroke a call to action from the american heart association. Circulation. 2011; 123(10): 1138-43.

[13] Brunner E, Cohen D, Toon L. Cost effectiveness of cardiovascular disease prevention strategies: a perspective on EU food based dietary guidelines. Public health nutrition. 2001; 4(2b): 711-5. 
[14] Bromley H, Williams F, Orton L, Flaherty MO, Capewell S Identifying the most effective and cost effective public health nutrition policy options for CVD prevention. Euroheart II Work Package 5.University of Liverpool; 2014.

[15] Sarrafzadegan N, Kelishadi R, Esmaillzadeh A, Mohammadifard N, Rabiei K, Roohafza H, et al. Do lifestyle interventions work in developing countries? Findings from the Isfahan Healthy Heart Program in the Islamic Republic of Iran. Bulletin of the World Health Organization. 2009; 87(1): 39-50.

[16] Mohammadifard N, Sarafzadegan N, Sadri G, Malekafzali H, Shahrokhi S, Tolouei H, et al. Isfahan Healthy Heart Program: The community-based interventional program for prevention and control of cardiovascular diseases, design, methods and first experiences.

[17] Shirani S, Khosravi A, Ansari R, Shahrokhi S, Sajjadi F, kelishadi $R$. The effect of an annual interventions on nutritional knowledge and practice of the population of the central region of Iran "Isfahan Healthy Heart Program".

[18] Kelishadi R, Sadry GH, Hashemi pour M, Sarraf Zadegan N, Alikhassy H, Bashardoust N, et al. Lipid profile and fat intake of adolescents: Isfashan healthy heart program-heart health promotion from children. koomesh. [Applicable]. 2003; 4(3): 63-72.

[19] Boshtam M, Sarafzadegan N, Zare K, Sadeghi S, Sajjadi F, Rabiei $\mathrm{K}$, et al. Effects of 5-year interventions on cardiovascular risk factors of factories and offies employees of isfahan and najafabad: worksite intervention projectisfahan healthy heart program. ARYA atherosclerosis. 2010; 6(3): 94.

[20] Sarafzadegan N, Rabiei k, Sadeghi m, Gharipour m, Hosieni $\mathrm{mh}$, Zolfaghari $\mathrm{b}$, et al. The outcome of secondary prevention interventions in a community based interventional Program: Isfahan Healthy Heart program. 2012; 14(1).

[21] Azizi F, Madjid M, Rahmani M, Emami H, Mirmiran P, Hadjipour R. Tehran Lipid and Glucose Study (TLGS): rationale and design. Iranian Journal of Endocrinology and Metabolism. [Original]. 2000; 2(2): 77-86.

[22] Azizi F, Ghanbarian A, Momenan AA, Hadaegh F, Mirmiran P, Hedayati M, et al. Prevention of non-communicable disease in a population in nutrition transition: Tehran Lipid and Glucose Study phase II. Trials. 2009; 10: 5 .
[23] Ramezankhani o, Mirmiran P, Azizi F. Effect of nutritional intervention on prevalence of metabolic syndrome and heart disease risk factors among urban Tehranians: Tehran Lipid and Glucose Study (TLGS). 2007; 9(1): 10-1.

[24] Salehi L, Haidari F. Efficacy of PRECEDE Model in Promoting Nutritional Behaviors in a Rural Society. Iranian Journal of Epidemiology. [Research]. 2011; 6(4): 21-7.

[25] Abedi P, Lee MHS, Kandiah M, Yassin Z, Shojaeezade D, Hosseini M, et al. Diet intervention to improve cardiovascular risk factors among Iranian postmenopausal women. Nutrition research and practice. 2010;4(6): 522-7.

[26] Sarafzadegan N, Alavi M, Rabiei k, Abedi H, Bahonar A, Zarfeshani S. Management of an Interventional CommunityBased Program Based on Information Resulted from Process Evaluation: Isfahan Healthy Heart Program. 2010; 7(3): 293303.

[27] Mahmoodi MR, Kimiagar M, Mehrabi Y, Rajab A, Hedayati $M$. The effects of omega-3 plus vitamin $\mathrm{E}$ and vitamin $\mathrm{C}$ plus zinc supplementations on plasma lipids and lipoprotein profile in postmenopausal women with type 2 diabetes. Iranian Journal of Nutrition Sciences \& Food Technology. 2009; 4(3): $1-14$.

[28] Haghighat N, Rostami A, Eghtesadi S, Shidfar F, Heidari I, Hoseini A. The effects of dark chocolate on lipid profile, apolipoprotein A-1, apo-lipoprotein B and inflammation in type-2 diabetic patients: A randomized clinical trial. Iranian Journal of Nutrition Sciences \& Food Technology. 2013; 8(2): 21-30.

[29] Yavari P, Siassi F, Jalali M, Mohammad K, Larijani B, Keshavarz A, et al. The impact of b-group vitamins and antioxidants on serum levels of apolipoprotein al and $b$ in type 2 diabetes. Iranian Journal of Diabetes and Metabolism. 2005; 5(1): 25-34.

[30] Sadeghiifar J, Taghinejad F, Taghinejadd H, Khodadadi E, Mousavi SM. Effect of Education on Knowledge and Attitude of Hospitalized Patients in CCU and Post CCU about Risk Factors of Cardio-Vascular Disease. Iranian Journal of Nursing Research. [Critical Care Nursing]. 2013; 8(1): 39-48. 